\title{
PENINGKATKAN BACAAN NUN MATI/TANWIN MENGGUNAKAN METODE CARD SORT
}

\author{
KISMATUN \\ SMP Negeri 1 Limpung \\ Email : Kismatunazza@gmail.com
}

\begin{abstract}
ABSTRAK
Tujuan dari penelitian ini adalah untuk meningkatkan tercapainya hasil pembelajaran mengenai bacaan nun mati atau tanwin di kelas VII B SMP Negeri 1 Limpung, Kabupaten Batang menggunakan metode card short atau seleksi kartu. Kenyataannya, mayoritas umat Islam di Indonesia masih banyak yang belum bisa membaca al-Quran dengan benar, termasuk siswa kelas VII B SMP Negeri 1 Limpung, di mana sebanyak 24 dari 36 siswa tidak mencapai batas minimal kompetensi pembelajaran. Kondisi tersebut disebabkan banyak faktor, di antaranya adalah pembelajaran PAI yang kurang menyenangkan. Bertolak dari latar belakang di atas, penelitian ini berusaha meningkatkan hasil pembelajaran dengan cara merubah proses pembelajaran menggunakan card short. Pada akhirnya, penelitian ini menemukan bahwa, penggunaan metode Card Sort dalam proses pembelajaran hukum bacaan nun mati/tanwin dapat meningkatkan motivasi dan hasil belajar peserta didik. Hal tersebut ditunjukkan oleh hasil belajar siswa yang mencapai indikator sesuai yang ditargetkan. Hal ini dibuktikan oleh peserta didik yang sudah memahami pengertian, huruf-huruf dan sekaligus memberikan contoh hukum bacaan nun mati/tanwin dengan benar, dan sudah mencapai indikator ketuntasan klasikal, yaitu mendapat nilai 90. Pada Siklus II, terdapat 5 peserta didik yang mendapat nilai 100 dan hanya 2 peserta didik yang belum tuntas.
\end{abstract}

Kata Kunci: Pendidikan Agama Islam, Tajwid, Card Short

\begin{abstract}
The purpose of this study was to improve the achievement of learning outcomes regarding reading nun mati or tanwin in class VII B of SMP Negeri 1 Limpung, Batang using the card short method. In fact, the majority of Muslims in Indonesia are still many who have not been able to read the Koran properly, including class VII B students of SMP Negeri 1 Limpung, where as many as 24 out of 36 students did not reach the minimum learning competency limit. This condition is caused by many factors, one of which is learning PAI which is not fun. Starting from the above background, this study seeks to improve learning outcomes by changing the learning process using short cards. In the end, this study found that the use of the Card Sort method in the learning process of the law of reading nun mati/tanwin can increase students' motivation and learning outcomes. This is indicated by student learning outcomes that achieve the targeted indicators. This is evidenced by students who already understand the meaning, letters and at the same time provide examples of the law of reading nun mati/tanwin correctly, and have reached the classical completeness indicator, which is getting a score of 90 . In Cycle II, there were 5 students who got a score 100 and only 2 students who have not completed.
\end{abstract}

Keywords: Islamic Education, Tajwid, Card Short

\section{PENDAHULUAN}

Tercapainya tujuan pembelajaran bergantung pada proses pembelajaran yang kondusif dan menyenangkan (Fakhrurrazi, 2018: 85-99; Kismatun, 2021: 266-275). Sebaliknya, kondisi pembelajaran yang tidak kondusif dan membosankan berakibat pada tingkat keberhasilan siswa yang rendah (Rohman, dkk., 2018: 95-108). Begitu juga dengan membaca al-Quran, agar siswa dapat membaca al-Quran dengan baik dan benar diperlukan pembelajaran tajwid (ilmu cara membaca al-Quran) yang menyenangkan. Kenyataannya, mayoritas umat Islam di Indonesia masih banyak yang belum bisa membaca al-Quran dengan benar (Mulyani, 2018: 202-210). Demikian pula siswa-siswi SMP Negeri 1 Limpung Kabupaten Batang, mereka belum mampu 


\section{STRATEGY : Jurnal Inovasi Strategi dan Model Pembelajaran Vol 2. No 1. Januari Tahun 2021 e-ISSN : 2798-5466 P-ISSN : 2798-5725}

memenuhi standar isi yang diatur dalam peraturan pendidikan Nasional No. 22/2006. Kondisi tersebut disebabkan banyak faktor, di antaranya adalah sedikitnya siswa yang memiliki buku pelajaran PAI, menganggap sulit materi PAI yang menyangkut bahasa arab, malas bertanya tentang pengetahuan agama baik kepada teman maupun guru, rendahnya minat untuk belajar agama, dan pembelajaran PAI yang kurang menyenangkan (Kismatun, 2021: 123-133). Bertolak dari latar belakang tersebut, ilmu tajwid harus diajarkan di SMP Negeri 1 Limpung dengan menyenangkan.

Hasil belajar siswa pada kompetensi hukum bacaan nun mati/tanwin dan mim mati di kelas VIIB SMP Negeri 1 Limpung, Kabupaten Batang, tahun pelajaran 2018/2019 menunjukkan bahwa, 36 siswa mendapatkan nilai rendah: hanya satu siswa yang mendapat nilai 95, tujuh siswa mendapat nilai 80-86, dua siswa mendapat nilai 72-75, dan 24 lainnya mendapat nilai di bawah KKM (72). Melihat kondisi tersebut, maka peneliti mencoba mengupayakan inovasi pembelajaran dengan menggunakan metode Card Sort (mensortir kartu). Metode Card Sort adalah strategi kolaboratif yang digunakan pendidik dengan maksud mengajak peserta didik untuk menemukan konsep dan fakta melalui klasifikasi materi yang dibahas dalam pembelajaran dengan menggunakan alat kartu (Anggreani, 2018: 364-370). Tujuan dari metode ini adalah guna meningkatkan motivasi belajar siswa, di mana metode pembelajaran sebelumnya berlangsung kurang menarik (Apriyani, 2019: 9-16). Oleh karenanya, penelitian ini berusaha untuk membandingkan hasil belajar siswa kelas VII B SMP Negeri 1 Limpung sebelum dan sesudah menggunakan metode card short.

\section{METODE PENELITIAN}

Penelitian ini merupakan penelitian tindakan (action research), karena penelitian dilakukan untuk memecahkan masalah pembelajaran di kelas (Prihantoro, 2019: 49-60). Penelitian ini juga termasuk penelitian deskriptif, karena menggambarkan tehnik pembelajaran diterapkan dan bagaimana hasil yang diinginkan dapat tercapai (Najamuddin, 2020: 22-28). Penelitian ini dilakukan selama tiga bulan yaitu pada bulan Januari 2019 sampai dengan Maret 2019 di kelas VII B SMP Negeri 1 Limpung Kabupaten Batang Provinsi Jawa Tengah. Objek penelitian tindakan kelas ini adalah siswa kelas VII B sebanyak 36 siswa, dengan rincian 18 putra dan 18 putri. Adapun langkah operasional penelitian ini adalah pertama adalah persiapan, yaitu: mempersiapkan siswa agar termotivasi, di mana metode pembelajaran ini menekankan pada keaktifan siswa dalam setiap proses pemebelajaran dengan menggunakan metode Card Sort.

Kedua adalah Perencanaan Tindakan Siklus I, yaitu peneliti merencanakan kegiatan pembelajaran dengan metode Card Sort pada materi pembelajaran Hukum Bacaan Nun Mati/Tanwin. Di sini peneliti menyusun RPP yang menggambarkan pelaksanaan pembelajaran dengan menggunakan metode Card Sort, yaitu peneliti menyiapkan kartu sesuai dengan Kompetensi Dasar. Isi kartu terdiri dari kartu induk (hukum bacaan nun mati/tanwin) dan kartu rincian yang terdiri dari huruf dan contoh bacaan. Selanjutnya, peneliti menyiapkan lembar kerja yang isinya berupa soal dan prosedur alur pelaksanaan pembelajaran dengan menggunakan metode Card Sort.

Ketiga adalah Pelaksanaan Tindakan Siklus I, yaitu Melaksanakan kegiatan sesuai dengan perencanaan tindakan siklus I yang terdiri dari dua pertemuan. Pertemuan pertama melaksanakan tahapan pembelajaran orientasi, merumukan masalah dan menyusun hipotesis. Sedangkan tahap kedua yaitu melaksanakan pengumpulan data, menguji hipotesis, dan menarik kesimpulan, sebagaimana yang termuat dalam Rencana Pelaksanaan Pembelajaran (RPP).

Keempat adalah Pengamatan dan Pengambilan Data dalam Siklus I, yaitu: peneliti dibantu seorang observer untuk melakukan observasi terhadap pelaksanaan tindakan untuk mengetahui sejauh mana pemanfaatan metode Card Sort. Observasi dilakukan bersamaan pelaksanaan tindakan dengan menggunakan lembar observasi yang telah dibuat. Aspek-aspek yang diamati adalah keaktifan siswa selama proses pembelajaran berlangsung, pemahaman 


\section{STRATEGY : Jurnal Inovasi Strategi dan Model Pembelajaran Vol 2. No 1. Januari Tahun 2021 e-ISSN : 2798-5466 P-ISSN : 2798-5725}

konsep dan ketuntasan klasikal pada akhir siklus. Hasil analisis data yang dilaksanakan dalam tahap ini digunakan sebagai acuan untuk melaksanakan siklus berikutnya.

Kelima adalah Refleksi dalam Siklus I, yaitu: peneliti mengumpulkan data tentang proses pembelajaran, hasil akhir siklus, kendala-kendala selama kegiatan pembelajaran dan perubahan yang terjadi untuk dianalisis dan dijadikan acuan untuk siklus selajutnya. Penelitian tindakan kelas ini dilakukan dalam dua siklus yaitu siklus I dan Siklus II, di mana masing-masing siklus dikenai perlakuan yang sama dan membahas satu kompetensi dasar yang diakhiri dengan tes di akhir masing-masing siklus.

Keenam adalah Pelaksanaan Siklus II, yaitu: penelitian yang dilaksanakan untuk mengetahui aktifitas dan sejauh mana peningkatan hasil belajar peserta didik dengan menggunakan metode Card Sort pada Kopetensi Dasar Hukum Bacaan Nun Mati/Tanwin. Hasil refleksi pada siklus I dianalisis dan dilihat pada aspek mana yang perlu perbaikan dan selanjutnya dibuat kembali perencanaan siklus II. Dalam pelaksanaan baik siklus I maupun siklus II masing-masing dikenai perlakuan yang sama dan membahas satu Kopensi Dasar dan diakhiri dengan tes di akhir masing-masing siklus.

Berikutnya, data hasil pengamatan dan tes diolah dengan analisis diskriptif untuk menggambarkan keadaan peningkatan motivasi belajar dan pencapaian indikator keberhasilan setiap siklus serta untuk menggambarkan keberhasilan pembelajaran dengan metode Card Sort yang dapat meningkatkan keaktifan dan pemahaman konsep hukum bacaan nun mati/tanwin. Motivasi dan hasil belajar siswa pada kompetensi hukum bacaan nun mati/tanwin dapat dikatakan meningkat apabila dapat memenuhi indikator kinerja, yaitu: pada akhir siklus I, diharapkan minimal $80 \%$ siswa di kelas VII B SMP Negeri 1 Limpung, Kabupaten Batang, mampu memahami hukum bacaan nun mati/tanwin, dengan memenuhi kreteria ketuntasan minimal yang ditetapkan sekolah. Pada akhir siklus II, diharapkan minimal 90\% siswa di kelas VII B SMP Negeri 1 Limpung kabupaten Batang mampu memahami hukum bacaan nun mati/tanwin, dengan memenuhi kreteria ketuntasan minimal yang ditetapkan sekolah yaitu 75 .

\section{HASIL DAN PEMBAHASAN}

Hasi penelitian tindakan kelas ini diperoleh dari tindakan pra siklus, siklus I dan siklus II. Hasil pra siklus herupa nilai atau hasil belajar peserta didik sebelum penelitian atau sebelum pembelajaran dengan menggunakan metode Card Sort dilaksanakan. Sedangkan hasil siklus I dan Siklus II berupa hasil belajar peserta didik dengan pembelajaran menggunakan metode Card Sort, dan hasil motivasi belajar berupa perubahan perilaku yang diperoleh melalui observasi, dan pengamatan.

\section{Hasil Penelitian Pra Siklus}

Proses pembelajaran sebelum pelaksanaan penelitian masih menggunakan metode ceramah. Guru mengawali pembelajaran dengan menjelaskan materi hukum bacaan nun/tanwin sambil menuliskan di papan tulis. Saat guru menjelaskan peserta didik diminta mendengarkan dan kalau ada yang dirasa tidak mengerti, peserta didik bisa langsung bertanya kepada guru. Setelah guru menjelaskan tentang materi hukum bacaan nun mati/tanwin siswa diminta untuk mencatat apa yang telah ditulis guru di papan tulis.

Pembelajaran selanjutnya guru memberi contoh soal yang berhubungan dengan materi hukum bacaan nun mati/tanwin. Dari soal tersebut diselesaikan oleh guru di papan tulis dengan peserta didik memperhatikan apa yang dikerjakan oleh guru. Kemudian peserta didik menyalin dari papan tulis ke buku tulis masing-masing. Melalui proses pembelajaran tersebut, keaktifan siswa dalam proses belajar mengajar masih sangat kurang, yaitu peserta didik cenderung masih banyak mendengarkan dalam memahami konsep hukum bacaan nun mati/tanwin, karena proses belajar mengajar masih didominasi oleh guru. Hal ini ditunjukkan dari rata-rata prosentase keaktifan siswa kelas VII B 55,6\% yang masih berasa jauh dibawah indikator keaktifan yang ditentukan yaitu $75 \%$. Untuk mengetahui pemahaman konsep hukum bacaan nun mati/tanwin kita peroleh dari dokumen nilai formatif matri hukum bacaan nun mati/tanwin dua tahun sebelumnya (nilai terlampir). Nilai rata-rata dua tahun tersebut dapat dilihat pada tabel berikut: 
Tabel 1. Pra Siklus Analisis Ulangan Harian Januari 2016

\begin{tabular}{|c|c|}
\hline Nilai Tertinggi & 90 \\
\hline Nilai Terendah & 5,3 \\
\hline Rata-rata Kelas & 70 \\
\hline Belum Tuntas & $59.9 \%$ \\
\hline Ketuntasan Klasikal & $40,1 \%$ \\
\hline
\end{tabular}

Tabel 2. Pra Siklus Analisis Ulangan Harian Januari 2017

\begin{tabular}{|c|c|}
\hline Nilai Tertinggi & 87 \\
\hline Nilai Terendah & 52 \\
\hline Rata-rata Kelas & 70 \\
\hline Belum Tuntas & $62,5 \%$ \\
\hline Ketuntasan Klasikal & $37,5 \%$ \\
\hline
\end{tabular}

Tabel 3. Pra Siklus Analisis Ulangan Harian Januari 2018

\begin{tabular}{|c|c|}
\hline Nilai Tertinggi & 93 \\
\hline Nilai Terendah & 62 \\
\hline Rata-rata Kelas & 72 \\
\hline Belum Tuntas & $46,8 \%$ \\
\hline Ketuntasan Klasikal & $53,2 \%$ \\
\hline
\end{tabular}

Berdasar nilai dua tahun terakhir kelas VII B, dapat disimpulkan bahsa peserta didik belum menguasai konsep hukum bacaan nun mati/tanwin. Hal ini dapat dilihat dari nilai ratarata kelas pada materi hukum bacaan nun mati/tanwin selama dua tahun adalah 69.6 yang masih berada di bawah indikator (KKM) yang ditentukan, yaitu 72. Berdasar nilai yang ada, dapat dilihat ketuntasan klasikalnya pada tabel berikut:

Tabel 4. Ketuntasan Klasikal Pra Siklus

\begin{tabular}{|c|c|}
\hline TAHUN & PROSENTASE \\
\hline 2016 & $56,3 \%$ \\
\hline 2017 & $59 \%$ \\
\hline 2018 & $47 \%$ \\
\hline
\end{tabular}

Dari tabel di atas dapat disimpulkan bahwa ketuntasan klasikal pembelajaran hukum bacaan nun mati/tanwin pada dua tahun terakhir adalah $43 \%$, di mana angka ini masih jauh di bawah indikator yang ditentukan, yaitu $80 \%$.

\section{Hasil Penelitian Siklus I}

Pelaksanaan pembelajaran siklus I dilaksanakan pada hari Jumat, 13 januari 2019. Pertama, peneliti melakukan Perencanaan Tindakan yang dilakukan secara opersional sebagai berikut:

1. Menyusun RPP yang menggambarkan pelaksanaan pembelajaran dengan menggunakan metode Card Sort, yaitu peneliti menyiapkan karti yang sesuai dengan Kompetendi Dasar. Isi kartu terdiri dari kartu induk (hukum bacaan nun mati atau tanwin dan mim mati) dan kartu rincian yang terdiri huruf dan contoh bacaan.

2. Guru mempersiapkan pesertadidik agar benar-benar termotivasi yang menekankan pada keaktifan peserta didik dalam proses pembelajaran dengan menggunakan metode Card Sort.

3. Menyiapkan lembar kerja yang isinya berupa soal dan prosedur alur pelaksanaan pembelajaran dengan metode Card Sort yang sesuai dengan kompet.

4. Guru menyiapkan kartu yang sesuai dengan Kompetensi Dasar. Isi kartu induk (hukum bacaan nun mati/tanwin) dan kartu rincian yang terdiri huruf dan contoh bacaan. 
5. Guru menyiapkan tempat duduk siswa dengan formasi huruf U.

Kedua adalah Pelaksanaan Tindakan, pada tahap ini guru melaksanakan pembelajaran hukum bacaan nun mati / tanwin menggunakan metode Card Sort. Adapun langkah-langkah yang peneliti tempuh adalah sebagai berikut:

1. Guru mengocok dan membagikan kartu kepada peserta didik hingga kartu tersebut habis.

2. Guru memerintahkan kepada peserta didik untuk mencari kartu induk (hukum bacaan) dengan mencocokkan teman se kelasnya.

3. Setelah kartu induk dan kartu rincian ketemu, guru memerintahkan masing-masing membentuk kelompok dan menempelkan hasinya di papan dengan urut.

4. Melakukan koreksi bersama setelah semua kelompok menempel kan hasilnya.

5. Guru meminta salah satu penanggung jawab kelompok untuk menjelaskan hasil sortir kartunya dan meminta komentar dari kelompok lainnya.

6. Guru memebrikan apresiasi setiap hasil kerja pesera didik.

7. Guru melakukan klarifikasi, simpulan dan tindak lanjut.

Ketiga adalah Hasil Pengamatan, yaitu peneliti menentukan tiga indikator keberhasilan yaitu: Keaktifan peserta didik dalam proses pembelajaran, Pemahaman Konsep, dan Ketuntasan Klasikal. Mengenai keaktifan peserta didik dalam proses pembelajaran, berdasar hasil pengamatan pada pelaksanaan pembelajaran siklus I dengan menggunakan angket keaktifan didapat nilai pada tabel sebagai berikut:

Tabel 5. Rata-rata prosentase Penilaian Keaktifan Siswa Pra Siklus dan Siklus I

\begin{tabular}{|c|c|}
\hline TAHAB & RATA-RATA KEAKTIFAN \\
\hline Pra Siklus & $55.63 \%$ \\
\hline Siklus I & $75.35 \%$ \\
\hline
\end{tabular}

Berdasarkan tabel di atas, dapat disimpulkan bahwa keaktifan peserta didik peserta didik mulai ada perubahan yaitu peserta didik mulai termotifasi untuk terlibat aktif meskipun belum optimal sesuai yang diharapkan. Peserta didik sudah banyak bertanya, menjawab pertanyaan, bekerja sama dalam menyelesaikan masalah baik secara individu maupun kelompok, sehingga dalam proses pembelajarangan peserta didik tidak lagi bergantung paga guru.

Mengenai pemahaman konsep, dari hasil penilaian pelaksanaan pembelajaran dengan menggunakan metode Card Sort (terlampir) yang rata-ratanya dapat dilihat pada tabel berikut:

Tabel 6. Siklus I Analisis Penilaian Harian

\begin{tabular}{|c|c|}
\hline Nilai Tertinggi & 100 \\
\hline Nilai Terendah & 52 \\
\hline Rata-rata Kelas & 76 \\
\hline Belum Tuntas & $34,4 \%$ \\
\hline Ketuntasan Klasikal & $65,6 \%$ \\
\hline
\end{tabular}

Berdasarkan tabel di atas dapat disimpulka bahwa peserta didik mulai memahami konsep hukum bacaan nun mati/tanwin. Hal ini ditandai dengan peserta didik siswa sudah mulai memahami pengertian, huruf-huruf dan sekaligus memberikan contoh hukum bacaan nun mati atau tanwin dan mim matidengan benar. Meskipun belum mencapai indikator yang ditetapkan yaitu 80 , akan tetapi sudah ada peningkatan rata-rata nilai yang signifikan.

Selanjutnya, mengenai ketuntasan klasikal, dari pengamatan yang dilakukan oleh peneliti diperolah ketuntasan klasikal pada siklus I ini yang dapat dilihat pada tabel berikut:

Tabel 7. Ketuntasan Klasikal Pra Siklus

\begin{tabular}{|c|c|}
\hline TAHAB & PROSENTASE \\
\hline Pra Siklus & $45,9 \%$ \\
\hline Siklus I & $65,6 \%$ \\
\hline
\end{tabular}

Dari tabel di atas dapat disimpulkan bahwa ketuntasan secara klasikal mengalami kenaikan yang signifikan dibanding dua tahun sebelumnya atau pra siklus, Akan tetapi masih 
ada beberapa peserta didik yang belum aktif dan termotivasi untuk belajar. Maka untuk ini perlu adanya tindakan lebih lanjut, dan sudah mencapai indikator ketuntasan klasikal yaitu 80. Pra siklus I ini tinggal 5 siswa yang belum tuntas tetapi terdapat 1 siswa yang, tetapi terdapat 1 peserta didik siswa yang mendapatkan nilai 100 .

Dengan demikian, secara keseluruhan pelaksanaan siklus I pembelajaran hukum bacaan nun mati atau tanwin dan mim mati nggunakan metode Card Sort menunjukkan adanya peningkatan motivasi, pemahan konsep, keaktifan dan ketuntasan klasikal yang signifikan. Dari hasil evaluasi siklus I menghasilkan beberapa catatan yang harus direfleksikan pada pelaksanaan pembelajaran siklus II, yaitu: peneliti kurang menguasai skenario pembelajaran dan masih nampak sedikit tegang belum sepenuhmya membaur dalam keceriaan peserta didik, sehingga dengan metode Card Sort belum optimal. Selain itu, masih banyak peserta didik yang pasif dan belum termotivasi untuk aktif dalam proses pembelajaran, sehingga hasil akhir siklus I belum tercapai $75 \%$.

\section{Hasil Penelitian Siklus II}

Siklus II dilaksanakan pada hari jumat, 14 Februari 2017. Pertama, peneliti melakukan Perencanaan Tindakan yang diejawantahkan pada langkah-langkah sebagai berikut:

1. Guru lebih rilek dan lebur dalm keceriaan peserta didik

2. Guru lebih memotivasi terhadap peserta didik untuk lebih aktif

3. Guru lebih memotivasi terhadap peserta didik untuk lebih mempersiapkan diri dengan belajar materi hukum bacaan nun mati atau tanwin dan mim mati baik secara individu maupun belajar kelompok

Kedua, peneliti melakukan Pelaksanaan Tindakan yang diejawantahkan pada langkahlangkah sebagai berikut:

1. Guru mengocok dan membagikan kartu kepada peserta didik hingga kartu tersebut habis

2. Guru memerintahkan kepada peserta didik untuk mencari kartu induk (hukum bacaan) an dengan kawan sekelasnya

3. Setelah kartu induk dan kartu rincian ketemu, guru guru memerintahkan masing-masing membentuk kelompok dan menempelkan hasilnya di papan dengan urut.

4. Melakukan koreksi bersama setelah semua kelompok menempelkan hasilnya

5. Guru meminta salah satu penanggung jawab kelompok untuk menjelaskan hasil sortir kartunya dan meminta komentar dari kelompok lainnya

6. Guru memberikan apresiasi setiap hasil kerja peserta didik

7. Guru melakukan klarifikasi, simpulan dan tindak lanjut

Ketiga, peneliti Pengamatan pengamatan pada hasil penelitian berdasar tiga indikator, yaitu: keaktifan peserta didik siswa dalam proses pembelajaran, Pemahaman Konsep, dan Ketuntasan Klasikal. Mengenai keaktifan peserta didik siswa dalam proses pembelajaran, didapat nilai (terlampir) yang rata-ratanya dapat dilihat pada tabel berikut ini:

Tabel 8. Rata-Rata Prosentase Penilaian Keaktifan peserta didik Pra Siklus, Siklus I dan siklus II

\begin{tabular}{|c|c|}
\hline TAHAP & RATA-RATA KEAKTIFAN \\
\hline Pra Siklus & $55,63 \%$ \\
\hline Siklus I & $75.35 \%$ \\
\hline SiklusII & $90.5 \%$ \\
\hline
\end{tabular}

Berdasarkan tabel di atas, dapat disimpulkan bahwa keaktifan peserta didik sudah banyak perubahan, yaitu peserta didik mulai termotinasi untuk terlibat aktif meskipun belum optimal, tinggal beberapa peserta didik saja yang belum aktif untuk bertanya, menjawab pertanyaan, bekerja sam dan menyelesaikan masalah baik secara individu maupun kelompok. Sehingga dalam proses pembelajaran peserta didik tidak lagi bergantung pada guru.

Mengenai pemahaman konsep, didapat nilai (terlampir) yang rata-ratanya dapat dilihat pada tabel berikut ini: 
Tabel 9. Analisis Penilaian Harian Siklus II

\begin{tabular}{|c|c|}
\hline Nilai Tertinggi & 100 \\
\hline Nilai Terendah & 67 \\
\hline Rata-Rata Kelas & 81 \\
\hline Belum Tuntas & $15,6 \%$ \\
\hline Ketuntasan Klasikal & $87,5 \%$ \\
\hline
\end{tabular}

Berdasarkan tabel di atas, dapat disimpulkan bahwa hasil belajar peserta didik sudah dapat mencapai indikator yang ditargetkan. Hal ini ditandai dengan peserta didik sudah memahami pengertian, huruf-huruf dan sekaligus memberikan contoh hukum bacaan nun mati/tanwin dengan benar, dan sudah mencapai indikator ketuntasan klasikal yaitu 90. Pada Siklus II ini tinggal 2 peserta didik yang belum tuntas dan terdapat 5 peserta didik yang mendapat nilai 100. Jadi secara keseluruhan pelaksanaan siklus II pembelajaran hukum bacaan nun mati atau tanwin dan mim mati menggunakan metode Card Sort dari hasil belajar peserta didik menunjukkan adanya peningkatam motivasi, pemahaman konsep, keaktifan dan ketuntasan klasikal yang sangat signifikan.

Mengenai Ketuntasan Klasikal, didapat nilai (terlampir) yang rata-ratanya dapat dilihat pada tabel berikut ini:

Tabel 10: Ketuntasan Klasikal Pra Siklus, Siklus I dan Siklus II

\begin{tabular}{|c|c|}
\hline TAHAB & KETUNTASAN KLASIKAL \\
\hline Pra Siklus & $47 \%$ \\
\hline Siklus I & $65,6 \%$ \\
\hline Siklus II & $87,5 \%$ \\
\hline
\end{tabular}

Dari tabel di atas dapat kita simpulkan bahwa ketuntasan secara klasikal mengalami kenaikan yang signifikan dibanding pra siklus dan siklus I, meskipun belum mencapai $100 \%$ atau tuntas semua, tetapi indikator klasikal, yaitu nilai 90 seperti yang ditargetkan, sudah tercapai. Jadi secara keseluruhan, pelaksanaan siklus II pembelajaran hukum bacaan nun /tanwin menggunakan metode Card Sort dapat meningkatkan motivasi dan hasil belajar peserta didik kelas VII B SMP Negeri 1 Limpung Kabupaten Batang.

Berdasar data di atas, tingkat Kemajuan Motivasi Belajar Peserta didik dapat dilihat pada tabel berikut:

Tabel 11. Tabel Peningkatan Motivasi Belajar peserta didik

\begin{tabular}{|c|l|c|c|c|}
\hline No & \multicolumn{1}{|c|}{ Indikator } & $\begin{array}{c}\text { Pra Siklus } \\
(\%)\end{array}$ & $\begin{array}{c}\text { Siklus I } \\
(\%)\end{array}$ & $\begin{array}{c}\text { Siklus II } \\
(\%)\end{array}$ \\
\hline 1 & $\begin{array}{l}\text { Peserta didik yang memiliki buku } \\
\text { tajwid }\end{array}$ & 20 & 60 & 95 \\
\hline 2 & $\begin{array}{l}\text { Peserta didik yang antusias } \\
\text { belajar mandiri }\end{array}$ & 30.5 & 65 & 95 \\
\hline 3 & $\begin{array}{l}\text { Peserta didik yang aktif dalam } \\
\text { proses pembelajaran }\end{array}$ & 20 & 78.5 & 83 \\
\hline 4 & Peserta didik yang mau bertanya & 15.5 & 25 & 50 \\
\hline 5 & $\begin{array}{l}\text { Peserta didik yang mau } \\
\text { menjawab pertanyaan }\end{array}$ & 75 & 88.5 & 95 \\
\hline 6 & $\begin{array}{l}\text { Peserta didik yang dapat } \\
\text { menjawab pertanyaan dengan } \\
\text { cepat dan benar }\end{array}$ & 45.5 & 83.9 & 93.5 \\
\hline
\end{tabular}

Selain itu, berdasar data di atas, Peningkatan Hasil Belajar dan Ketuntasan Belajar Peserta didik dapat dilihat pada tabel berikut: 


\section{Tabel 12. Tingkatan Hasil Belajar Peserta didik Dan Ketuntasa Belajar Peserta didik}

\begin{tabular}{|c|l|c|c|c|}
\hline No & \multicolumn{1}{|c|}{ Indikator } & Pra Siklus & $\begin{array}{c}\text { Siklus I } \\
(\%)\end{array}$ & $\begin{array}{c}\text { SiklusII } \\
(\%)\end{array}$ \\
\hline 1 & Nilai Rata-rata & 72 & 76 & 81 \\
\hline 2 & Nilai tertinggi & 93 & 100 & 100 \\
\hline 3 & Nilai terendah & 62 & 52 & 67 \\
\hline 4 & $\begin{array}{l}\text { Jumlah peserta didik yang tuntas } \\
\text { belajar }\end{array}$ & 17 & 21 & 27 \\
\hline 5 & $\begin{array}{l}\text { Jumlah peserta didik yang belum } \\
\text { tuntas belajar }\end{array}$ & 15 & 11 & 5 \\
\hline 6 & $\begin{array}{l}\text { Prosentase peserta didik yang tuntas } \\
\text { belajar }\end{array}$ & $53,2 \%$ & $65,6 \%$ & $87,5 \%$ \\
\hline 7 & $\begin{array}{l}\text { Prosentase peserta didik yang belum } \\
\text { tuntas belajar }\end{array}$ & $46,8 \%$ & $34,4 \%$ & $15,6 \%$ \\
\hline
\end{tabular}

\section{KESIMPULAN}

Berdasarkan hasil penelitian tindakan kelas yang telah dilakukan, disimpulkan bahwa: penggunaan metode Card Sort dalam proses pembelajaran hukum bacaan nun mati/tanwin dapat meningkatkan motivasi dan hasil belajar peserta didik. Hal tersebut ditunjukkan oleh hasil belajar peserta didik yang mencapai indikator sesuai yang ditargetkan. Hal ini ditandai dengan peserta didik sudah memahami pengertian, huruf-huruf dan sekaligus memberikan contoh hukum bacaan nun mati/tanwin dengan benar, dan sudah mencapai indikator ketuntasan klasikal, yaitu mendapat nilai 90. Pada Siklus II, terdapat 5 peserta didik yang mendapat nilai 100 dan hanya 2 peserta didik yang belum tuntas.

\section{DAFTAR PUSTAKA}

Anggreani, Asteria Lindiyana, Choirul Huda, and Eka Sari Setianingsih. (2018) "Pengaruh Strategi Card Sort Berbantu Media Gambar terhadap Prestasi Belajar IPA.” Jurnal Ilmiah Sekolah Dasar 2, no. 4, p. 364-370.

Apriyani, Evi. (2019) "Penggunaan Metode Card Sort Dalam Upaya Menyelesaikan Persamaan

Linear Satu Variabel (Peneltian Tindakan Kelas di Kelas VII-F SMP Negeri 3

Tasikmalaya)." Jurnal Wahana Pendidikan 5, no. 3, p. 9-16.

Fakhrurrazi. (2018) "Hakikat pembelajaran yang efektif." At-Tafkir 11, no. 1, p. 85-99.

Kismatun. (2021) "Contextual Teaching and Learning Dalam Pendidikan Agama Islam.” Teacher: Jurnal Inovasi Karya Ilmiah Guru 1, no. 2, p. 123-133.

Kismatun. (2021) "Pengembangan Pendidikan Agama Islam Menggunakan Metode Inquiry." Teaching: Jurnal Inovasi Keguruan dan Ilmu Pendidikan 1, no. 4, 266-275.

Mulyani, Dewi, Imam Pamungkas, and Dinar Nur Inten. (2018) "Al-Quran Literacy for Early Childhood with Storytelling Techniques." Jurnal Obsesi: Jurnal Pendidikan Anak Usia Dini 2, no. 2, p. 202-210.

Najamuddin, M. (2020) "Pengembangan Pembelajaran Dengan Pemberian Balikan Terhadap Hasil Belajar Ips Siswa.” Jurnal Paedagogy 2, no. 1, 22-28.

Prihantoro, Agung, and Fattah Hidayat. (2019) "Melakukan Penelitian Tindakan Kelas." Ulumuddin: Jurnal Ilmu-ilmu Keislaman 9, no. 1, p. 49-60.

Rohman, Ahmad Aunur, and Sayyidatul Karimah. (2018) "Faktor-faktor yang mempengaruhi rendahnya motivasi belajar siswa kelas XI." Jurnal At-Taqaddum 10, no. 1, p. 95-108. 